\title{
Basic nutrition assistance for head and neck cancer patients
}

\author{
Baş ve boyun kanseri hastaları için temel beslenme yardımı \\ Erdem Atalay Çetinkaya, ${ }^{1}$ Mehmet Refik Sezgin, ${ }^{2}$ İbrahim Çukurova ${ }^{3}$ \\ ${ }^{1}$ Department of Otolaryngology, Antalya Atatürk State Hospital, Antalya, Turkey \\ ${ }^{2}$ Department of Oncology, Private Antalya Hospital, Antalya, Turkey \\ ${ }^{3}$ Department of Otolaryngology, İzmir Tepecik Training and Research Hospital, İzmir, Turkey
}

\begin{abstract}
Head and neck cancer patients live under a high risk of nutrition deficiency. There is an increasing body of evidence to approve intensive nourishment help to these patients. The purposes of nourishment support are to avert and handle dietary deficiency, augment tolerance to cancer therapy, reduce the adverse effects of cancer therapy, and increase quality of life. The European Society for Clinical Nutrition and Metabolism guidelines are the first evidence-based European recommendations for nourishment for cancer patients. In this review, we summarized malnutrition assessments, nutritional problems, and nutritional counselling and patient experiences.

Keywords: Head and neck cancer; malnutrition; nutritional support.
\end{abstract}

Healthy nutrition is particularly substantial if patient has head and neck cancer (HNC) as both the disease and therapies are likely to alter the eating habits. The diagnosis and therapy of HNC may result in acute toxicities that impact the ability to eat and the eating experience during and after therapy. Bodily, sentimental and sociable deprivations in connection with the eating habits have been observed. Confirming the importance of eating difficulties and the changed meaning of food is necessary to ensure patients receive the proper management and support to best manage these challenges in a timely manner. ${ }^{[1]}$

\section{MALNUTRITION and CANCER CACHEXIA}

The food requirements of patients with HNC differ individually. The physician, special dietitian,
$\ddot{O} Z$

Baş ve boyun kanseri hastalarında yüksek malnütrisyon riski vardır. Bu hastalarda yoğun beslenme desteğini teşvik etmek için giderek artan kanıtlar bulunmaktadır. Beslenme desteğinin amaçları beslenme bozukluğunu engellemek ve tedavi etmek, antitümör tedaviye dayanma gücünü artırmak, antitümör tedavinin yan etkilerini azaltmak ve yaşam standardını artırmaktır. Avrupa Klinik Beslenme ve Metabolizma Derneği kılavuzları kanser hastaları için beslenme hakkında Avrupa'dan ilk kanıta dayalı önerilerdir. Bu derlemede, beslenme bozukluğu değerlendirmeleri, beslenme sorunları, beslenme danışmanlığ ve hasta deneyimleri özetlendi.

Anahtar sözcükler: Baş ve boyun kanseri; malnütrisyon; beslenme desteği.

and caregivers are able to assist HNC patients specify their nutrition aims and design methods to assist them. Healthy nutrition can help during and after their treatments.

There are also extensive distinctions between the food requirements for patients with diverse kind of HNC. Many HNC are more adverse to nutrition than others. Therefore patients possess a particular risk for nutrition deficiency, particularly undernutrition. Consequently, a deficiency of strength and nutrients ensues. The outcome is weight reduction and a diminishment of muscle tissue. This can unfortunately influence physical activity as well as resistance to infection. Accordingly patients with $\mathrm{HNC}$ are more susceptible to complications during and after therapy. It might also cause a delayed recovery process. Malnutrition is seen in $8-85 \%$ of patients 
with cancer during some part of the cancer treatment. Patients with HNC, esophageal, lung, gastrointestinal and pancreatic cancers especially have high risk for nutritional problems. ${ }^{[1,2]}$

A significant sign of malnutrition is unintended weight loss. Such weight loss might cause a deficient nourishing condition and an aggravating situation. Exhaustion, deficiency of hunger, disgust for food, flavor change and diminished muscle power may cause malnutrition. Malnutrition has an unfavorable impact on HNC patients' healthiness. It may seriously endanger HNC patients' life standard. Additionally, nutrition deficiency enhances the chance of complications through operation or further repercussions over or after irradiation or chemotherapy. When nutrition deficiency is extensive and lengthy, hospitalization will be required and the recovery will be sluggish. The earlier nutrition deficiency is identified, the earlier therapy can be initiated with suitable nutritive nutritional intervention..$^{[2]}$

Cachexia, a condition controlled by several factors, is defined by progressive weight loss, constantly, but not all the time, accompanied by anorexia. ${ }^{[3]}$ Cancer cachexia generally causes with reduction of body muscle and fat. The nutritional situation should be appraised as quickly as possible with the diagnosis of cancer. Essential nutritional assistance should be provided promptly. Primarily, oral intake is assessed and enhanced by dietary counseling. In the event of insufficient oral intake, enteral and parenteral nutritional assistance are needed. The purpose of dietary assistance is to avert and cure nutrition deficiency, enhance endurance to cancer treatment, reduce the unfavorable reactions of cancer treatment and upgrade the quality of life. As part of dietary assistance, progestins and steroids used as appetite stimulators may further participate in cachexia therapy. Cachexia symptoms are seen around $80 \%$ of advanced HNC patients and $40 \%$ of newly diagnosed patients and is responsible for about $20 \%$ of the causes of death. ${ }^{[2-4]}$ First, the current situation should be determined and risk analysis should be done. After all, the follow-up process should be identified, and if there is risk of cachexia, a nutrition plan should be made (Figure 1).

\section{NUTRITIONAL PROBLEMS}

Head and neck cancer patients' nutritional problems usually vary leading to a variety of treatment options. Head and neck cancer patients commonly experience diminished oral intake because of pain, chewing and swallowing problems due to local symptoms. ${ }^{[5]}$

Surgical treatments usually have mechanicalfunctional and emotional side effects for malnutrition and especially after surgical approaches patients may be afraid and feel pain and have problems with dysphagia. On the other hand chemotherapy may cause so many side effects, such as nausea, vomiting, mouth sores and dry mouth. Radiotherapy (RT) related nutritional problems differ in appearance, time and severity due

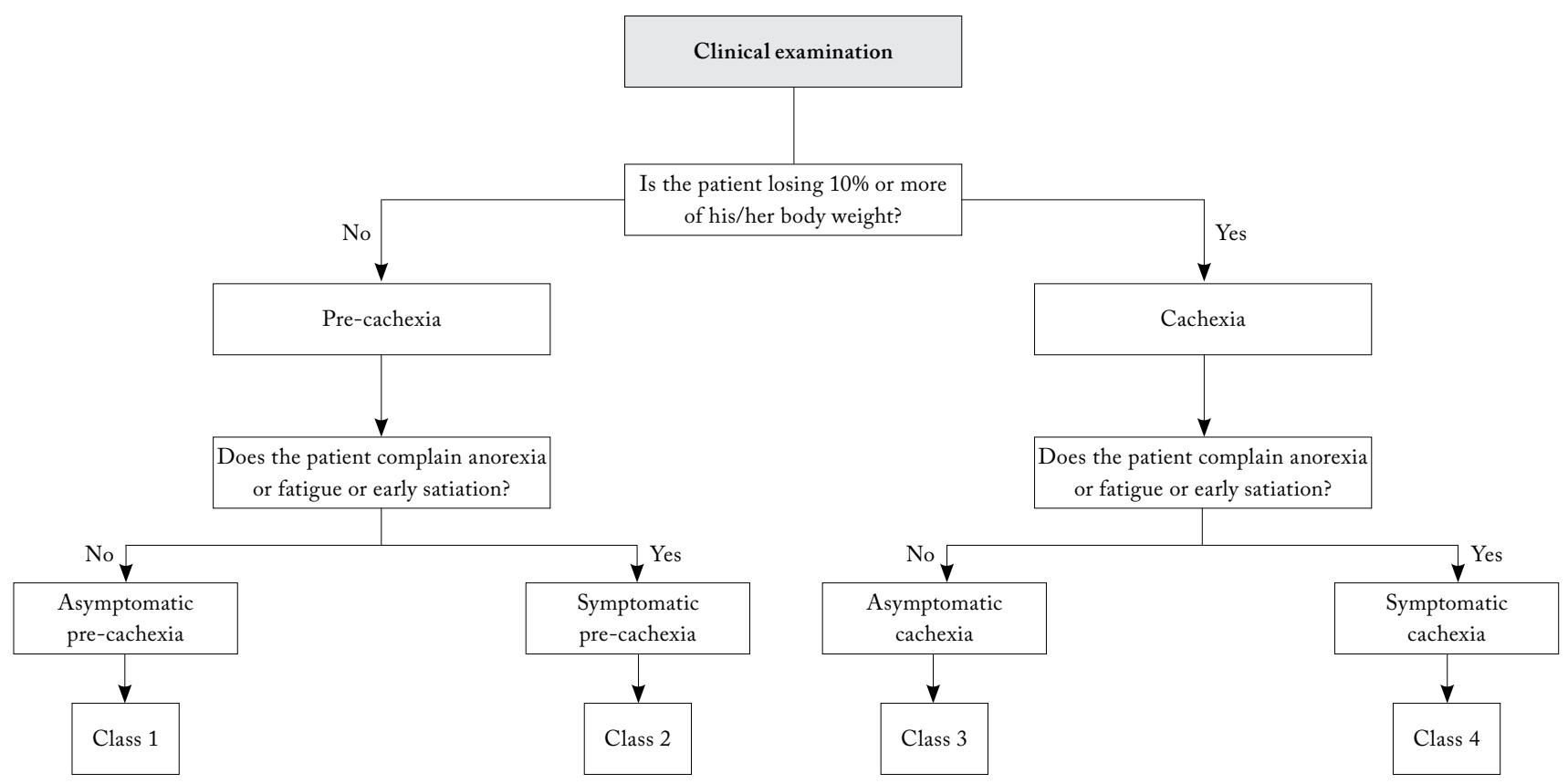

Figure 1. Classification and definition of cancer cachexia. ${ }^{[9]}$ 
to treatment and personal differences. ${ }^{[6,7]}$ The risk for malnutrition increases with age and presence of cancer, and is particularly common in older cancer patients and frequently, cancer treatments should induce the nutritional abnormalities. ${ }^{[7,8]}$ Weight loss before and during chemotherapy and radiation therapy is frequently noticed. Weight loss before but not during therapy has been connected with worse staying alive. ${ }^{[8]}$ The results of malnutrition contain deficiency of immune functions, performance condition, muscle function, and life standard. Moreover, reactions to chemotherapy are diminished, chemotherapy-caused toxicity and complications are more common and intense. Depression and exhaustion also have an important impact on HNC patients' comfort. Besides, cancerrelated nutrition deficiency is linked with high health care-related costs. ${ }^{[9-11]}$

\section{NUTRITION SCREENING}

A set of simple and approved nutrition assessment instruments can be used to detect malnutrition risks in cancer patients (e.g., Malnutrition Screening Tool, Mini Nutritional Assessment Short Form Revised, Nutrition Risk Screening, and the Malnutrition Universal Screening Tool). Patients with HNC should be screened upon diagnosis, in care homes or on admission to hospitals. Also patients should be screened during check out in outpatient or general practitioner clinics, and periodicaly depending on clinical status. Nutritional assessment is a comprehensive assessment of dietary intake, anthropometrics, and physical examination often conducted by dieticians, nurses or clinicians after simple screening has identified at-risk patients. ${ }^{[6]}$

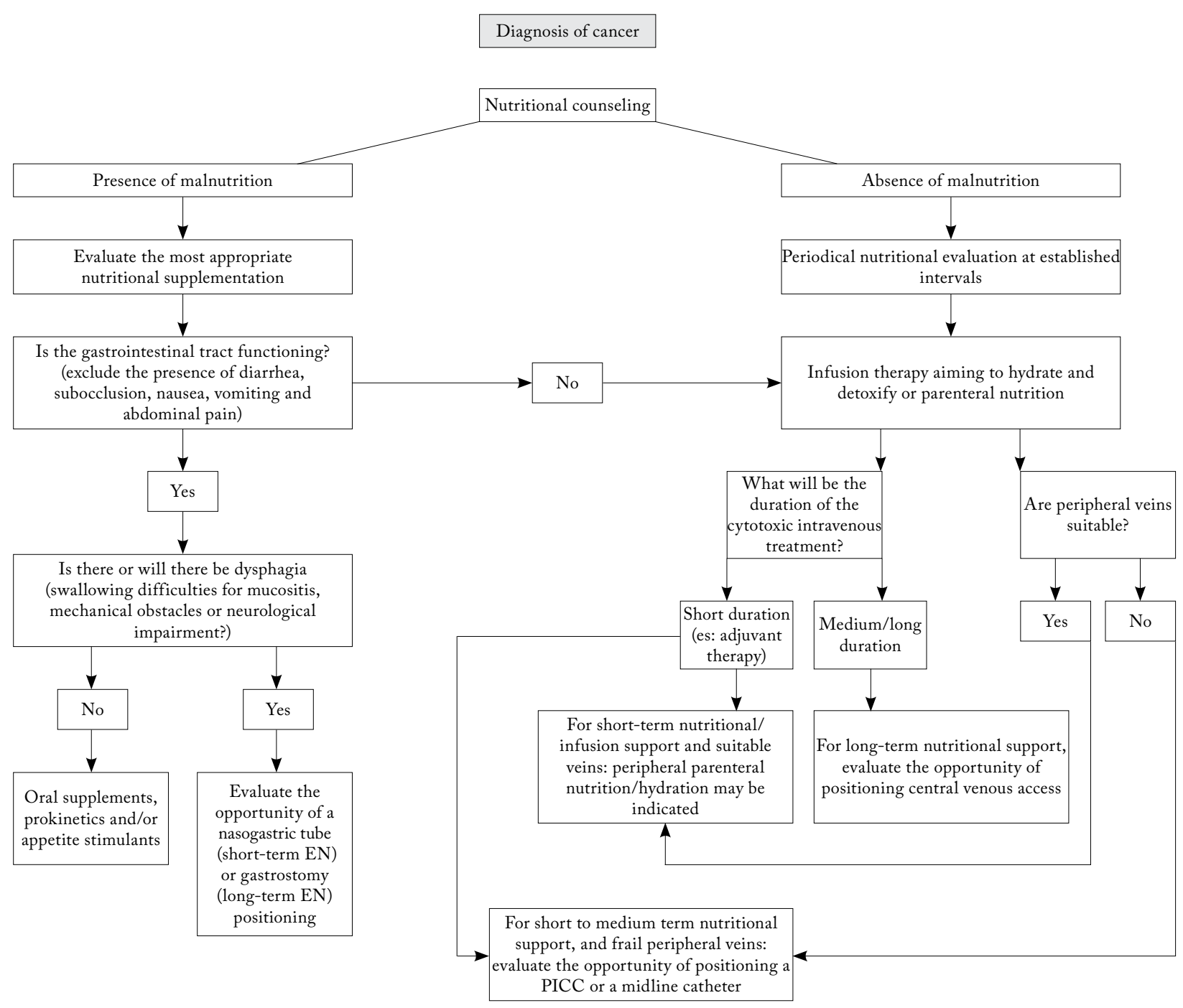

Figure 2. Nutritional counseling. ${ }^{[13]}$ EN: Enteral nutrition; PICC: Peripherally inserted central venous catheter. 
To identify nutritional nuisances at an early stage, to regularly adjust nutritional intake, weight change and body mass index, beginning with cancer diagnosis and repeated depending on the stability of the clinical situation, is advised by The European Society for Clinical Nutrition and Metabolism (ESPEN). The ESPEN guidelines on enteral nourishment are the first evidence-based European suggestions for enteral nutrition. ${ }^{[5-10]}$

Immediately after major surgery, HNC patients generally need watery nutrients and may require medical food, either enteral or parenteral. Generally this is transient. Occasionally salivary glands do not operate fairly following surgery or radiation therapy. Therefore, the saliva by means which food is made easier to swallow and digest, is not available any longer. Occasionally patients can not open the mouth adequately for suitable nutrient admission. Many times, the community encompassing HNC patients do not notice rapidly that nutrient admission - transiently or constantly - can only exclusively occur in watery condition. In the period following surgery or radiation therapy, all patients make effort to return to standard nutrition. However, eating and swallowing difficulties may persist for a long-time. It may also require long-time to eat solid nutrients, that conceives communal issues when eating with family and friends. Medical nutrition can support as extra admission of nutrient. This may be required when patients with cancer return to work. ${ }^{[9-11]}$

\section{PATIENT EXPERTS WITH HNC}

Nutrition and swallowing difficulties in HNC can differ from patient to patient. Additionally the cures occasionally have to be examined on a private basis. While dietitians supply patients with counsel on the excellent nourishment, speech therapists know a great deal about feeding and nutrient ingestion. Scientists and investigators are often trying to find the best food for a healthy and long life and consider answers for nutrition deficiency and dehydration. However, the question "can patients eat it" is occasionally not noted. NHC therapist in the some European countries considered this question and published a data booklet on this, written from the patients' perspective. Personal experience demonstrates that nutrients should be delicate, soft and supplied in small pieces or readily divisible. Water should be supplied when eating. The use of sauce helps the food easier to swallow. All spicy ingredients and grains should be averted. Selected samples of plates favored by therapists include jam and sandwich spread, bananas and mangoes, cooked vegetables, lasagna, mushrooms and pasta, smoothies and milkshakes, and meat in casserole or ragout form. Aside from favored products, there are also those that are not liked by expert patients. Do not use large pieces, hard and or dry meats that require considerable chewing. The less favored examples include cornflakes, chips, crackers, foods without sauce, nuts, chili sauce, pepper and hot spices. ${ }^{[10-12]}$

\section{NUTRITIONAL COUNSELING}

The best plan is to prepare team of health care professionals conscious of the tools to detect cancer patients at risk of nutrition deficiency and early meddling and reexamination during cancer therapy. ${ }^{[11-13]}$ It is very important not just for treatment; the eating training has a marked consequences on treatment for HNC. ${ }^{[14]}$

The most asked question is "which nutritional support (hypercaloric, immunonutrition, low fat etc.) is the best, if we have to choose one." The answer is simple: usable and low complication potential is the best option. During nutritional support, no nutritional support option is clearly the best option. Additionally, a nutritional support cannot provide a curative effect. The right choice is that treatment with the least risk for complications. ${ }^{[15]}$

In conclusion, general nutritional goals for $\mathrm{HNC}$ patients are; ; ${ }^{[7,15]}$

- Weight maintenance during and after treatment,

- Successful, continuous completion of treatment,

- Minimal, if any, weight loss in overweight or obese patients until patient is fully recovered from treatment and is able to eat without difficulties,

- Weight maintenance during transitional feeding from enteral nutritional support.

The HNC patients have a much greater daily necessity of nutrients during their treatment. We propose that current nutritional assessment tools should be routinely used in the work-up of HNC patients.

\section{Declaration of conflicting interests}

The authors declared no conflicts of interest with respect to the authorship and/or publication of this article.

\section{Funding}

The authors received no financial support for the research and/or authorship of this article.

\section{REFERENCES}

1. Hopkinson JB. Psychosocial impact of cancer cachexia. J Cachexia Sarcopenia Muscle 2014;5:89-94. 
2. Tisdale MJ. Mechanisms of cancer cachexia. Physiol Rev 2009;89:381-410.

3. Fearon K, Strasser F, Anker SD, Bosaeus I, Bruera E, Fainsinger RL, et al. Definition and classification of cancer cachexia: an international consensus. Lancet Oncol 2011;12:489-95.

4. Langer CJ, Hoffman JP, Ottery FD. Clinical significance of weight loss in cancer patients: rationale for the use of anabolic agents in the treatment of cancer-related cachexia. Nutrition 2001;17:1-20.

5. Ravasco P, Monteiro Grillo I, Camilo M. Cancer wasting and quality of life react to early individualized nutritional counselling! Clin Nutr 2007;26:7-15.

6. Bauer J, Capra S, Ferguson M. Use of the scored PatientGenerated Subjective Global Assessment (PG-SGA) as a nutrition assessment tool in patients with cancer. Eur J Clin Nutr 2002; 56:779-85.

7. Ghadjar P, Hayoz S, Zimmermann F, Bodis S, Kaul D, Badakhshi H, et al. Impact of weight loss on survival after chemoradiation for locally advanced head and neck cancer: secondary results of a randomized phase III trial (SAKK 10/94). Radiat Oncol 2015;10:21.

8. Chang PH, Yeh KY, Huang JS, Chen EY, Yang SW, Wang $\mathrm{CH}$. Chemoradiotherapy in elderly patients with advanced head and neck cancer under intensive nutritional support.
Asia Pac J Clin Oncol 2015;11:228-35.

9. Bozzetti F. Nutritional support of the oncology patient. Crit Rev Oncol Hematol 2013;87:172-200.

10. Karvinen K, Bruner B, Truant T. The teachable moment after cancer diagnosis: Perceptions from Oncology nurses. Oncol nurs forum 2015;42:602-9.

11. Isenring E. Consensus-based nutritional recommendations for patients with head-and-neck cancer. Curr Oncol 2011;18:165-6.

12. Shiley SG, Hargunani CA, Skoner JM, Holland JM, Wax MK. Swallowing function after chemoradiation for advanced stage oropharyngeal cancer. Otolaryngol Head Neck Surg 2006;134:455-9.

13. Santarpia L, Contaldo F, Pasanisi F. Nutritional screening and early treatment of malnutrition in cancer patients. J Cachexia Sarcopenia Muscle 2011;2:27-35.

14. Brockbank S, Miller N, Owen S, Patterson JM. Pretreatment information on dysphagia: exploring the views of head and neck cancer patients. J Pain Symptom Manage 2015;49:89-97.

15. Ganzer H, Touger-Decker R, Byham-Gray L, Murphy BA, Epstein JB. The eating experience after treatment for head and neck cancer: A review of the literature. Oral Oncol 2015;51:634-42. 